\title{
RECENT DEVELOPMENTS WITH MUSCLE RELAXANTS AND THEIR ANTAGONISTS
}

\author{
Ronald D. Miller
}

THE EMPHASIS in this paper will be on recent developments with muscle relaxants and their antagonists and some concepts which of ten cause confusion will be discussed.

The development of analytical techniques to measure muscle relaxant or antagonist concentrations in blood and other body tissues is of prime importance. ${ }^{1-3}$ We can now study the pharmacokinetics and pharmacodynamics of these drugs. Why is this important clinically? $K a t z^{4}$ and others have emphasized the variable response of patients to muscle relaxants. Much of this variability is not just inherent, but can be explained in part by pharmacokinetics. What diseases and physiological changes alter the rate at which the relaxant leaves plasma and is eliminated (pharmacokinetics)? What diseases and physiological changes alter sensitivity of the neuromuscular junction to muscle relaxants (pharmacodynamics)? If the answers to these questions were available, we could be more selective in relaxant dose and avoid much of the "variability" described by Katz ${ }^{4}$ and others. Initial work in this area will be presented.

Although the search for a short-acting nondepolarizing muscle relaxant has occasionally been encouraging, no such relaxant is yet available. ${ }^{5.6}$ In the antagonist area, 4-aminopyridine has been proposed as a better antagonist than either neostigmine or pyridostigmine; this possibility will be evaluated.

\section{Tests of Neuromuscular Transmission}

\section{Peripheral nerve stimulation}

Stimulating a peripheral nerve (usually the ulnar nerve at the wrist or elbow) and visually observing contraction of the fingers is the method most commonly advocated for monitoring neuromuscular function clinically. The stimula-

Ronald D. Miller, M.D. Professor of Anesthesia and Pharmacology, University of California, San Francisco, California 94143.

From the Annual Royal College Lecture at the Annual Meeting of the Canadian Anaesthetists' Society, Ottawa, Ontario, June 18-22, 1978.

Supported by USPHS Grant P50 GM15571-11, USPHS Grant IROI GM 26403-01 and Anesthesia Pharmacology Research Foundation.

Canad. Anaesth. Soc. J., vol. 26, no. 2, March 1979 tion need not be restricted to the arm. Stimulating the facial nerve or nerves of the lower extremity and observing the magnitude of the resulting muscle contraction can also be used for monitoring neuromuscular function.

Both magnitude and type of neuromuscular blockade can be detected by this type of monitoring. However, quantitative conclusions must be guarded. Because of the wide margin of safety of neuromuscular function, a reduction in the contractile response to peripheral nerve stimulation is not quantitatively proportional to the action of relaxant at the receptor. For example, Waud and Waud have found the twitch response (i.e. adduction of the thumb) is not reduced unless more than 70 per cent of the receptors are occupied by a non-depolarizing relaxant. ${ }^{7}$ Twitch is completely eliminated when 90 per cent of the receptors are occupied. In spite of this limitation, the twitch can be used as a quantitative monitor. Adjusting relaxant administration to maintain a faint but perceptible muscle contraction (twitch) in response to peripheral nerve stimulation assures adequate operating conditions while avoiding excessive relaxant administration. Even if complete abolition of the twitch occurs, if one waits until the twitch reappears before administering more relaxant, the incidence of.relaxant overdose can be reduced.

Obviously, subtle degrees of neuromuscular blockade cannot be observed by monitoring the twitch. The neuromuscular junction must be stressed by a stimulus which is greater and longer in intensity. A sustained muscle contraction in response to a tetanic stimulus for five seconds is such a stimulus. Unfortunately tetanic stimuli are painful and are therefore of limited value in detecting subtle neuromuscular blockade in the unanesthetized patient, such as one in the recovery room. The "train-of-four" method of stimulation as proposed by Ali, et $a l .{ }^{8}$ alleviates pain problems. This test also does not require a control or prerelaxant twitch. The "train-of-four" offers significant advantages; however, 70 per cent of the receptors can be occupied and still permit a normal response. 9 Thus, although more sensitive than the single twitch, it is no more sensitive than the tetanic stimuli at $50 \mathrm{~Hz}$. 


\section{Respiration}

Sustained adequate ventilation is of prime importance, particularly during stresses such as airway obstruction or vomiting. Despite the huge number of relaxant studies in the literature there are few studies correlating tests of neuromuscular function with adequacy of ventilation and the conclusions are often incomplete. Walts, et $a . .^{10}$ concluded that sustained muscle contraction in response to tetanic stimulus $(30 \mathrm{~Hz})$ is a good test because it correlates with greater than 90 per cent recovery of vital capacity and maximum voluntary ventilation in human volunteers. They concluded that the head-raising test is an unreliable index of recovery because it does not return to control when vital capacity and tetanic stimulation are within 90 per cent of control. Perhaps the head-raising test is more sensitive. In fact, Johansen, et al." found head-lift and hand-grip strength to be 38 per cent and 48 per cent of control when both inspiratory and expiratory flow rates are greater than 90 per cent of control.

Obviously, the most sensitive test stresses the neuromuscular junction most. Sensitivity depends on both the intensity and duration of the stress applied. For example, a head-lift and grip test may be an insensitive test when applied for one second or very sensitive when applied for 15 seconds. Obviously it becomes extremely important to define tests very carefully when making comparisons..$^{2}$ In view of the scanty information available, I can only recommend that there are probably several tests available which are sensitive when applied in a way to stress the neuromuscular junction which includes both duration and intensity of stimulation.

\section{Receptor occlusion techniques}

Reference has previously been made to the fraction of receptors which may be occupied during responses to various tests of neuromuscular function. Work on this subject has been done primarily by Waud and Waud. ${ }^{7.9 .13}$ No one has the ability to count the number of receptors occupied by a relaxant. Rather, Waud and Waud estimated the fraction of receptors (without really knowing the absolute number of receptors) which must be unblocked by relaxant for tests of neuromuscular function to be normal. The technique estimates the fraction of receptors blocked by a nondepolarizing relaxant by determining a dose-response depolarization curve from various agonist doses (succinylcholine) in the absence and presence of the blocker (d-tubocurarine).
The fraction of receptors unblocked by nondepolarizing relaxant or still available for neuromuscular transmission can be estimated from the dose ratio of the agonist and blocker. For example, in the presence of d-tubocurarine, $100 \mathrm{nmol}$ of succinylcholine might be required to produce the same degree of depolarization that $10 \mathrm{nmol}$ produced without d-tubocurarine. Since ten times more succinylcholine is required with dtubocurarine, then 10 per cent of the receptors are still free (or 90 per cent of the receptors are blocked). All other tests used to measure neuromuscular function allow a normal response with a significant number of receptors still blocked, even at a tetanic stimulus of $200 \mathrm{~Hz}$. These results suggest that no test is available to determine whether all receptors are free of relaxant.

\section{Clinical conclusions}

In spite of the above considerations, we do not know what proportion of receptors must be available or how sensitive a test must be to ensure adequate muscle strength to overcome airway obstruction and to permit effective coughing. I have concluded that one should not rely on one test, but should utilize as many tests as is practically possible. For example, when the operative procedure is nearly finished and the patient is still under anesthesia, I frequently use a tetanic stimulus of $50 \mathrm{~Hz}$, twitch height, tidal volume, and expiratory force to determine whether a neuromuscular blockade has been antagonized completely. Expiratory force can be determined by removing the rebreathing bag and occluding the outlet and observing the pressure on the circuit gauge (R.L. Katz: personal communication). One should compare this pressure with expiratory force determined before relaxant administration. It is of prime importance to use several tests and to stress the neuromuscular junction to detect possible subtle degrees of neuromuscular blockade.

Several authors recommend titrating the amount of acetylcholinesterase inhibitor to a specific end point, which is most frequently a tetanic stimulus of 30 to $50 \mathrm{~Hz} .^{4.7 .10}$ Even though several tests may indicate normal neuromuscular function, I administer slightly more neostigmine or pyridostigmine than necessary to effect a sustained contraction in response to a tetanic stimulus of 30 to $50 \mathrm{~Hz}$. For example, if neostigmine $2.5 \mathrm{mg}$ were sufficient to restore twitch height to control levels and sustain tetanus at 50 
$\mathrm{Hz}$, l would administer neostigmine $3.0 \mathrm{mg}$ in an effort to ensure the availability of additional receptors needed to overcome airway obstruction.

Non-pharmacokinetic Factors Which May ALter MUSCle RELAXANT OR ANTAGONIST ACTIVITY

\section{Intensity of neuromuscular blockade}

The degree of neuromuscular blockade at the time when neostigmine is administered determines the speed and extent of antagonistic action by neostigmine. When twitch height is more than 20 per cent of control, time from neostigmine administration $(2.5 \mathrm{mg})$ to attainment of contro] twitch height is 3-14 minutes. With twitch heights less than 20 per cent of control, recovery takes 8-29 minutes. ${ }^{14} \mathrm{My}$ observations indicate that most attempts to antagonize the block occur when a 90 to 100 per cent depression of twitch tension exists. It should not be surprising if $30-45$ minutes are required for twitch height to return to control levels or even longer for a sustained contraction in response to a tetanic stimulus of $50 \mathrm{~Hz}$.

\section{Relaxant being antagonized}

The neuromuscular blockade from gallamine resists reversal by neostigmine more than those from d-tubocurarine and pancuronium. Monks ${ }^{15}$ found that neostigmine-induced recovery from a d-tubocurarine or pancuronium block was faster than recovery from a gallamine block. He concluded that a d-tubocurarine or pancuronium block is "more easily reversed" than a gallamine block. Although these studies infer that gallamine, which required more neostigmine for reversal, is less desirable, all the gallamine blocks in our study ${ }^{16}$ were completely antagonized by neostigmine. Monks ${ }^{15}$ did not follow the twitch response until complete recovery occurred. Does the fact that gallamine requires more neostigmine for antagonism represent an undesirable clinical effect? I suspect not.

\section{Acid-hase state}

Respiratory acidosis may augment a nondepolarizing neuromuscular blockade but, more importantly, limits and prevents its antagonism (Figure 1)..$^{17.18}$ In other words, it is impossible to antagonize a nondepolarizing neuromuscular blockade in the presence of significant respiratory acidosis $\left(\mathrm{Pa}_{\mathrm{CO}_{2}}>6.65 \mathrm{kPa}\right.$ [50 torr] $)$. This has many clinical ramifications. For example, if a patient hypoventilates in the recovery room, at-
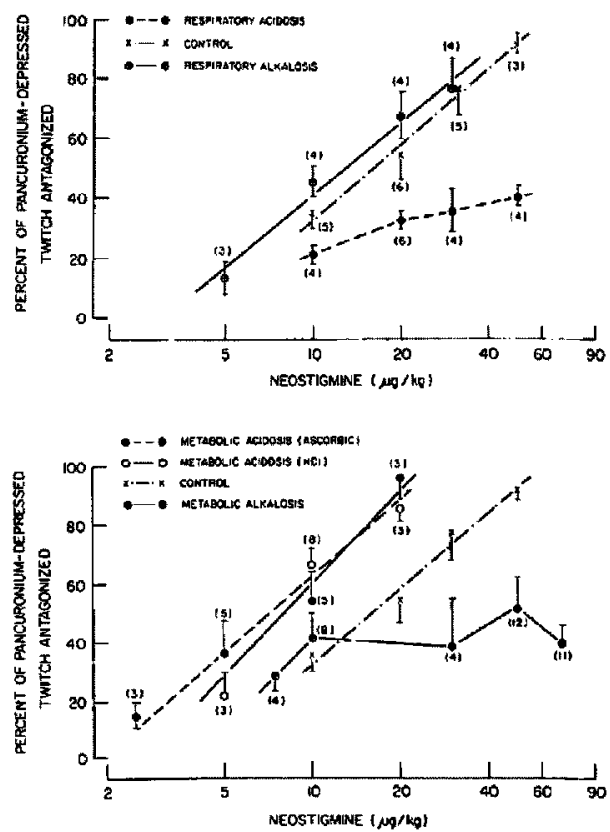

FIGURES 1 AND 2 The effect of respiratory (Figure 1, top) and metabolic (Figure 2, bottom) acid-base changes on neostigmine antagonism of pancuroniumdepressed twitch tension (mean \pm SEM). The numbers in parentheses represent the number of cats studied at each dose. With respiratory alkalosis, metabolic acidosis and control, the lines represent analysis of linear regression. With respiratory acidosis and metabolic alkalosis the lines are drawn to aid interpretation. (With the permission of the authors and publisher. $)^{18}$

tempts to antagonize a residual d-turbocurarine block may fail. Administration of narcotics to relieve pain may increase the likelihood of this untoward event. Such a sequence contains an element of potential positive feedback where respiratory depression produces more acidosis and relaxant effect and, hence, more respiratory depression.

Although metabolic acidosis might also be predicted to prevent antagonism by neostigmine, this has not been substantiated. ${ }^{17,18}$ To our surprise, metabolic alkalosis, but not metabolic acidosis, prevented neostigmine antagonism of d-tubocurarine and pancuronium (Figure 2). ${ }^{17.18}$ These results suggest that extracellular hydrogen ion concentration $\left(\mathrm{CH}^{+}\right)(\mathrm{pH})$ per se may not be as important as changes in electrolytes and intracellular $\mathrm{cH}^{+}(\mathrm{pH})$. Metabolic alkalosis produced by infusion of sodium bicarbonate will also de- 
crease extracellular potassium and calcium levels. I found recently that if calcium and potassium levels are not allowed to decrease, metabolic alkalosis does nothing to a pancuronium neuromuscular blockade or its antagonism by neostigmine. The se findings suggest that looking at extracellular $\mathrm{cH}^{+}(\mathrm{pH})$ alone is insufficient to predict the effect of acid-base changes on neostigmine antagonism of nondepolarizing relaxants. Frequently a bolus of bicarbonate will transiently increase twitch tension. It is then concluded that metabolic alkalosis antagonizes a non-depolarizing block. I submit that this type of study has little or no relation to the clinical situation in which metabolic alkalosis has existed for several hours or days with associated electrolyte abnormalities. What does the clinician do with such confusing information concerning metabolic acid-base changes? Because so many factors are involved, the simplest and most obvious advice is to maintain a normal acid-base state.

\section{Electrolytes}

Although the subject of several review articles, ${ }^{19,20}$ little data is available on the effect of electrolyte imbalance on a non-depolarizing neuromuscular blockade and its antagonism by neostigmine. Low extracellutar concentrations of potassium apparently enhance the block from non-depolarizing relaxants and diminish the ability of neostigmine to antagonize the block. This prediction is based on the increase in end-plate transmembrane potential which results from a higher ratio of intracellular to extracellular potassium. Thus a decrease in extracellular potassium causes hyper-polarization and increases resistance to depolarization. However, the end-plate is oniy one part of the contractile mechanism, the remainder of which may be affected in a contrary fashion. For example, a low extracellular potassium level also should increase the transmembrane polential of the motor nerve terminal. Although the threshold for depolarization is increased once depolarization occurs, the nerve action potential will be larger, and this should augment acetyicholine release and post. junctional depolarization. Which of the opposing prejunctional and post-junctional changes from hypokalaemia are dominant?

Cohen $^{20}$ and Feldman ${ }^{19}$ speculate that, in chronic diseases, both intracellular and extracellular potassium decrease without affecting trans-membrane potential. Therefore, the response to muscle relaxants and their antagonists

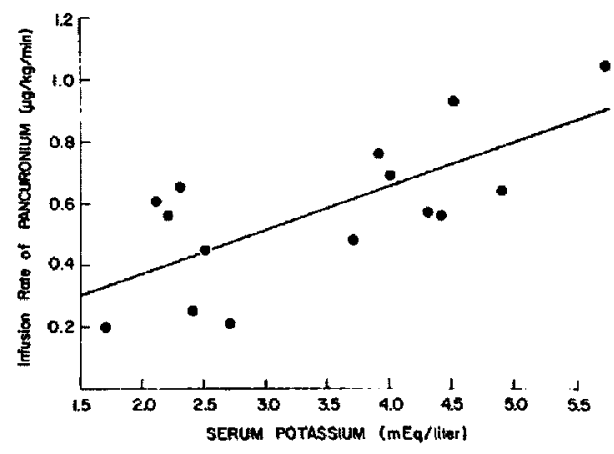

FIGURE 3 Relationship between infusion rate of pancuronium necessary to maintain 90 per cent depression of twitch tension and serum potassium concentrations. Each dot represents the infusion rate and potassium concentration from one cat. The line represents analysis of linear regression. (With the permission of the aut hor and publisher.) ${ }^{2 z}$

should be normal. However, the muscle transmembrane potentials are changed in patients who are severely ill or even bedridden for a few days." Also, severe dehydration should concentrate the relaxant present in plasma, thereby increasing relaxant activity.

As with acid-base studies, a common error with some studies, in my opinion, is to administer a bolus of some electrolyte such as potassium and to assume that this resembles hyperkalaemia which may be present in a patient for hours or days. Studies in these types of patients are difficult because many factors exist which may alter relaxant action. We attempted to develop an animal model which would simulate the type of chronic hypokalaemia which anaesthetists may observe in patients. Cats were given a diuretic without potassium supplement for 15 days. We found that less pancuronium was required for neuromuscular blockade and more neostigmine was required for antagonism (Figure 3). 22 Even though the differences were small, we were always able to antagonize the block completely. Assuming this animal model approximates the clinical situation, changes in potassium appear to be of minor consequence.

Pharmacokinetic factors which may alter muscle relaxant or antagonist activity

The rate of disappearance of relaxant from blood is characterized by a rapid initial disappearance which is followed by a slower decay (Figure 4). Distribution to tissues is the major cause of the initial decrease, whereas the slower 


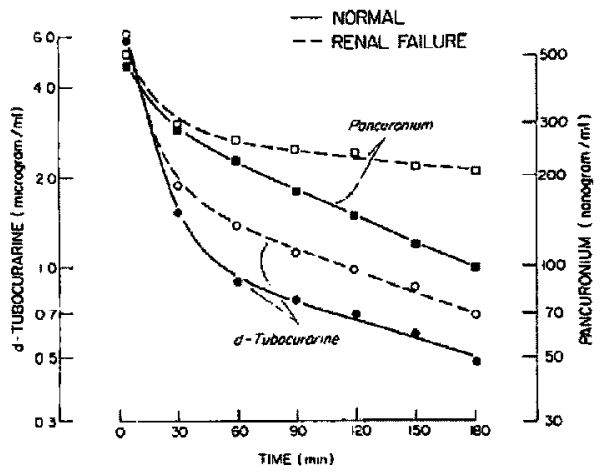

Figure 4 Rates at which the plasma concentrations of d-tubocurarine and pancuronium decrease in patients with and without renal failure. Note that the decay rates are about the same in patients with normal renal function. However, the decay rate is much slower in patients with renal failure receiving pancuronium than those receiving d-tubocurarine. The data for pancuronium were obtained from McLeod, et al..$^{26}$ and d-tubocurarine from Miller, et at ${ }^{23}$

decay is due to excretion (Figure 4). Because relaxants are highly ionized, they do not cross all membranes and have a limited volume of distribution. The volume of distribution of relaxants ranges from 80 to $140 \mathrm{ml} \cdot \mathrm{kg}^{-1}$ which is not much larger than blood volume. ${ }^{23}$ If the volume of distribution is reduced then the potency of muscle relaxant may be augmented. For example, if a disease state such as renal failure renders plasma proteins unable to bind d-tubocurarine, then the volume to which d-tubocurarine is distributed would be reduced, making more available to the neuromuscular junction. ${ }^{24}$ Reduced plasma protein binding would allow a more rapid excretion of d-turbocurarine by the kidney. The kidney eliminates d-tubocurarine by glomerular filtration. However, proteins are not filtered. So if d-tubocurarine is highly bound to protein, it will not be excreted readily by glomerular filtration. This would not be a factor with pancuronium, which is not bound to proteins to any extent.

As indicated previously, pharmacokinetics and dynamic studies will help define those diseases and physiological changes which may alter sensitivity of the neuromuscular junction or the rate of elimination of muscle relaxants. Such information has not been available because we lacked the analytical methods to measure muscle relaxant and antagonist concentrations in blood and other body tissues. Such techniques are now available. We also have pharmacokinetic models
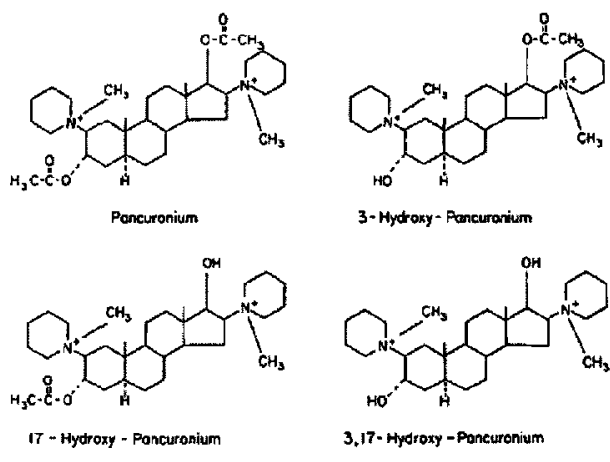

3- Hycroky- Pencuronium

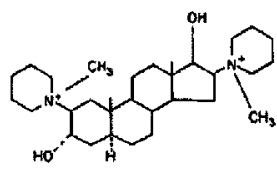

3,17- Hydroxy - Paneuronium

Figure 5 Formula of pancuronium and its deacetylated metabolites.

which can handle the many variables the clinical scene presents. So, in the coming years we should have a better understanding of what conditions alter the action of muscle relaxants and their antagonists.

\section{Metabolism of pancuronium}

Unlike d-tubocurarine, about 15 to 40 per cent of an injected dose of pancuronium is deacetylated into $3-\mathrm{OH}, 17-\mathrm{OH}$, or $3,17-\mathrm{OH}$ pancuronium (Figure 5). Of those metabolites, 3-OH pancuronium predominates. The metabolites have been studied individually in anaesthetized patients. ${ }^{25}$ The $3-\mathrm{OH}$ metabolite is the most prominent in quantity and is the most potent; it is half as potent as pancuronium (Figure 6). Although the 3-OH metabolite has a duration of action similar to that of pancuronium (Figure 7) and has similar pharmacokinetics (Figure 8 ), several questions remain. Is the block from the metabolite easily antagonized? Do the metabolites accumulate in patients with renal failure?

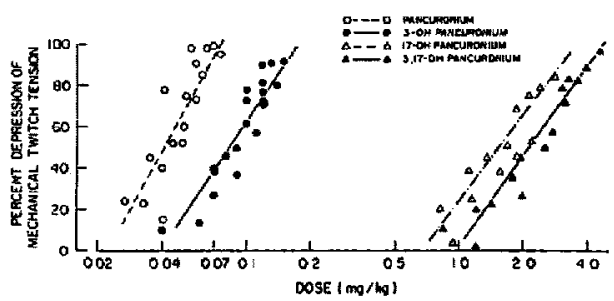

Figure 6 Correlation between dose of muscle relaxant and depression of mechanical twitch tension. The lines represent analys is of linear regression. The correlation coefficients were $0.87,0.92,0.93$ and 0.96 for pancuronium and its $3-\mathrm{OH}, 17-\mathrm{OH}$ and $3,17-\mathrm{OH}$ derivatives respeclively. (With permission of author and publisher.) $)^{2 s}$ 


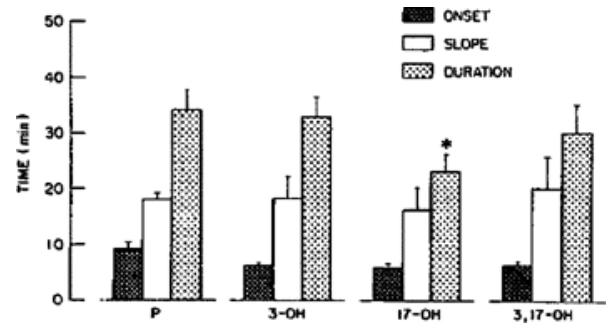

Figure 7 Onset times, duration of neuromusculitr blockade and slope of l'ecovery (mean \pm S.E.) for pancuronium and its $3-\mathrm{OH}, 17-\mathrm{OH}$ and $3,17-\mathrm{OH}$ derivatives using the mechanical iwitch as the measure. Onsel is defined as that time from relaxant administration to peak depression of twitch tension. Duration is the time from relaxant administration unt il recovery of $50 \mathrm{per}$ cent of the depressed iwitch tension. Slope of recovery is defined as the time from 25 to 75 per cent recovery of the depressed twitch tension. The "*" means significantly different from pancuronium. (With per. mission of athor and publisher. $)^{25}$

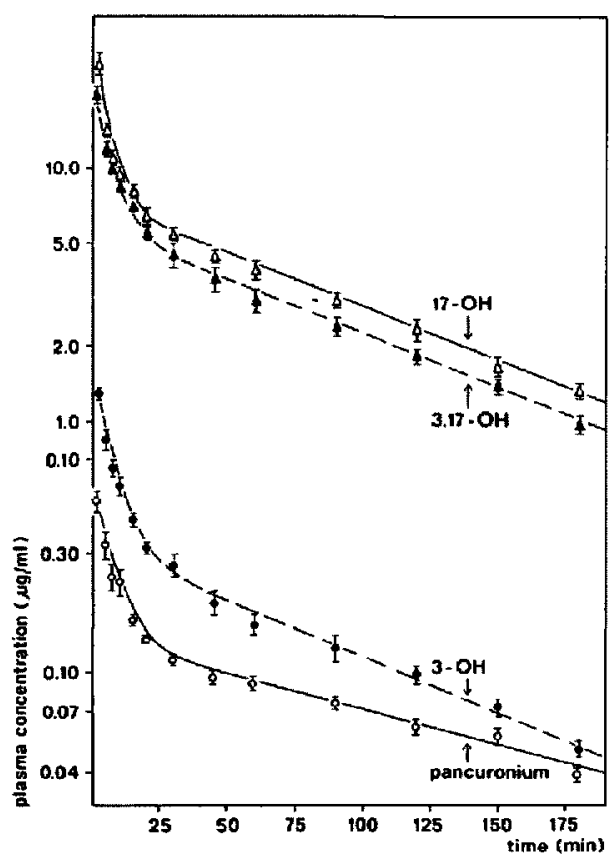

Figure 8 Correlation between time and plasma concentration of pancuronium and its $3-\mathrm{OH}, 17-\mathrm{OH}$ or 3,17-OH derivatives. The dots and bracket represent mean \pm S.E. (With permission of author and pub(isher.) ${ }^{25}$
Answers to these questions will soon appear. There is little doubt that the metabolism of pancuronium has clinical importance.

\section{Renal failure}

Renal failure can profoundly affect the pharmacokinetics of relaxants. Gallamine and decamethonium are entirely dependent on renal excretion for their elimination. Recent studies in man indicate that pancuronium is more dependent on renal excretion than is d-tubocuratine (Figure 4). ${ }^{23,26.27}$ Even though the rate at which pancuronium and d-tubocurarine disappear from plasma is about the same with normal renal function, pancuronium disappears much slower during renal failure (Figure 4). Probably about 80 per cent of an injected dose of pancuronium is eliminated in the urine while only 40 per cent of $d$ tubocurarine is. Thus d-tubocurarine probably is the preferred non-depolarizing relaxant in patients without renal function. ${ }^{23}$

Although the data in Figure 4 are convincing that $d$-tubocurarine is less dependent on renal excretion for its elimination, this conclusion requires some caution. The immunoassay method measures only unchanged d-tubocurarine. The fluorimetric method does not distinguish between pancuronium and its melabolites. The slow rate at which pancuronium appears to leave the plasma (Figure 4) during renal failure may represent cumulation of inactive metabolites. In spite of this analytical problem, I still believe that dtubocurarine is less dependent on renal excretion for its elimination than is pancuronium.

\section{Hepatic failure}

Several authors have suggested that relaxant requirement is increased ${ }^{20}$ in patients with biliary or liver disease. Most of these opinions were based on rather scanty information. One might predict a prolonged neuromuscular blockade since both d-tubocurarine and pancuronium are partly dependent on biliary excretion for their elimination. Somogyi, et al. ${ }^{28}$ found that the neuromuscular blockade and elimination half-life of pancuronium were prolonged in patients with extra-hepatic obstruction. P. Duvaldestin (personal communication) found that in patients with hepatic cirrhosis the volume of distribution is increased and the elimination half-life is prolonged. Because pancuronium is distributed to a larger volume with cirrhosis, a larger dose of pancuronium may well be required to achieve a given neuromuscular blockade. However, once that neuromuscular blockade has been achieved, 


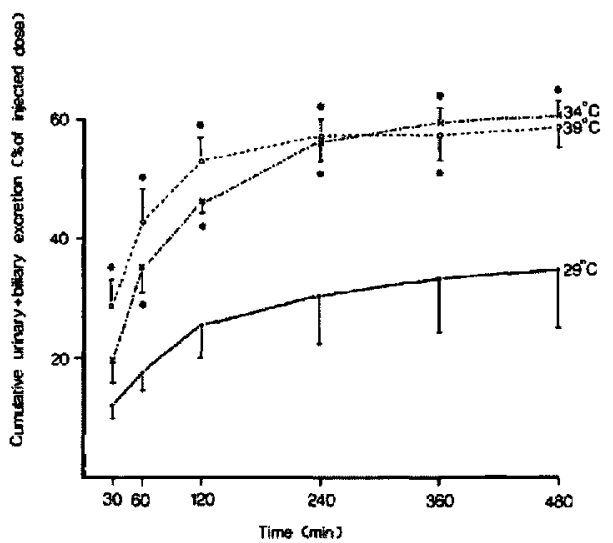

Figure 9 Correlation between time after pancuronium $0.12 \mathrm{mg} / \mathrm{kg}$ and percentage of injected dose appearing in urine and bile. (With permission of author and publisher.) $)^{\text {so }}$

it should last longer because elimination is delayed. So, even though a larger dose of pancuronium may be required initially, subsequent doses should be smaller than may be expected.

\section{Hypothermia}

Hypothermia prolongs a d-tubocurarine 29 and pancuronium ${ }^{30}$ neuromuscular blockade. Blocks induced by both relaxants are prolonged because of delayed urinary and biliary excretion (Figure 9). With pancuronium the block is also prolonged because of decreased metabolism into inactive metabolites. ${ }^{30}$ Therefore hypothermia probably prolongs the block of pancuronium more than that of d-tubocurarine.

\section{Antagonism}

We have three drugs available which will antagonize a non-depolarizing neuromuscular blockade. Edrophonium has a duration of action which is too short to be useful. The relative merits of neostigmine and pyridostigmine have been discussed previously. ${ }^{2}$ The new drug in this area is 4-aminopyridine. This drug has been studied extensively in animals and found to antagonize a non-depolarizing neuromuscular blockade by increasing both evoked and spontaneous release of acetylcholine from the motor nerve terminal, rather than by inhibition of acetylcholinesterase. ${ }^{31}$ Studies in animals indicate that 4-aminopyridine has several advantages over neostigmine and pyridostigmine which include longer duration of action, antagonism of antibiotic neutomuscular blockades when neo-

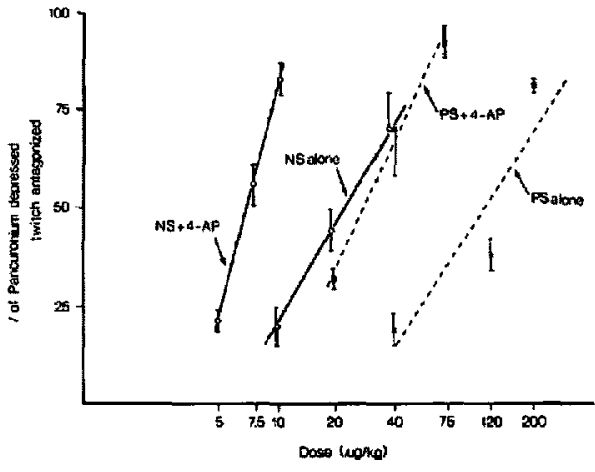

Figure 10 Correlation between neostignine (NS) and pyridostigmine (PS) alone and with 4-aminopyridine, $0.35 \mathrm{mg} / \mathrm{kg},(4-\mathrm{AP}$ ) and percentage of pancuronium-depressed Iwitch antagonized. The lines represent analysis of linear regression. Each dot or $X$ represents the mean $\pm 1 S$.E. of three patients. (With permission of author and publisher. $)^{33}$

stigmine often fails and no muscarinic stimulation, so that no atropine is required. In spite of these advantages, I predict that 4-aminopyridine alone will not be useful clinically. Unfortunately, the doses of 4-aminopyridine required for complete antagonism (>1 $\mathrm{mg} \cdot \mathrm{kg}^{-1}$ ) also stimulate the central nervous system and cause postoperative restlessness and confusion (unpublished data, $\mathrm{S}$. Agoston). Obviously what is needed is a 4aminopyridine which does not cross the blood brain barrier.

Although 4-aminopyridine appears not to be useful alone as an antagonist, it may offer a significant advantage when combined with neostigmine. 4-Aminopyridine markedly potentiates the antagonist activity of both neostigmine and pyridostigmine. ${ }^{32}$ For example, 4-aminopyridine $20 \mathrm{mg} / 70 \mathrm{~kg}$ does nothing by it self. Yet it reduces the amount of neostigmine or pyridostigmine required by $60-70$ per cent (Figure 10). ${ }^{33}$ The combination of neostigmine or pyridostigmine with 4-aminopyridine may diminish or eliminate the disadvantages that these drugs have when given individually. The amount of atropine required is reduced by $60-70$ per cent. Also, possibly a predictable antagonism of an antibiotic neuromuscular blockade may exist. I believe these potential advantages are sufficient to warrant further studies with the combination of 4-aminopyridine with neostigmine or pyridostigmine.

\section{Question}

The most common question I am asked is "What should be done if 2.5 to $3.0 \mathrm{mg}$ of neostig- 
mine or 10 to $15 \mathrm{mg}$ of pyridostigmine fail to antagonize a non-depolarizing neuromuscular blockade?" These doses of neostigmine and pyridostigmine will antagonize most non-depolarizing blocks in the a verage adult patient. ${ }^{14.16}$ Additional antagonist should not be given unless certain questions have been answered first. These questions are:

1. Has enough time been allowed for the neostigmine or pyridostigmine to antagonize the block? 14

2. Is the neuromuscular blockade too intense to be antagonized?

3. What is the acid-base and electrolyte status?

4. What is the temperature?

5. Is the patient receiving any drugs which may make antagonism difficult?

6. Has excretion of the relaxant been reduced? Except for question number 5, this review has provided the background to answer these questions. The background for question 5 has been reviewed elsewhere. ${ }^{12.34}$ Quite often, answers to these questions will provide the reason for failure of neostigmine or pyridostigmine to reverse the block.

\section{SUMMARY}

The major advance from which we are beginning to reap the benefits is the development of analytical techniques to measure muscle relaxant or antagonist concentrations in blood and body tissues. We now can define the alterations that disease and physiological changes make in the rate at which the relaxant leaves the plasm (pharmacokinetics), and in the sensitivity of the neuromuscular junction to muscle relaxants (pharmacodynamics). This information will allow a more selective approach to relaxant dose and help us to avoid the wide variability previously described. ${ }^{4}$ The search for a short-acting non-depolarizing muscle relaxant is not yet over. In the antagonist area, 4-aminopyridine has advantages over neostigmine and pyridostigmine in that concomitant atropine administration is not required and antibiotic-induced neuromuscular blocks are more consistently antagonized. Because 4-aminopyridine may have potentially undesirable side-effects, smaller doses in combination with neostigmine may be advantageous. Lastly, several factors which may augment a non-depolarizing neuromuscular blockade and/ or interfere with antagonism are reviewed. If neostigmine 2.5 to $3.0 \mathrm{mg} / 70 \mathrm{~kg}$, or pyrido- stigmine 10 to $15 \mathrm{mg} / \mathrm{kg}$ does not antagonize the block, those factors should be considered before additional antagonist is given.

\section{RÉSUMÉ}

De nombreux auteurs, dont Katz, ont souligné la variabilité de la réponse des malades aux relaxants musculaires; cette variabilité n'est pas intrinsèque aux drogues elles-mèmes mais peut partiellement s'expliquer; ainsi, la pharmacocinétique cherche à identifier les facteurs qui modifient le taux de l'élimination plasmatique du relaxant musculaire et de son côté, la pharmacodynamie cherche à identifier les causes de la modification de la sensibilité de la plaque neurale aux relaxants musculaires. Quand on aura rêponse à ces interrogations, on saura utiliser les myorésolutifs en contournant cette variabilité.

\section{Test d'évaluation de la ransmission} newromusculaire

A. Stimulation d'un nerf périphérique: La stimulation d'un nerf périphérique constitue la méthode la plus couramment employée pour le monitorage de la fonction neuromusculaire. Cependant, 70 pour cent des récepteurs doivent être neutralisés par le relaxant avant d'observer une réduction de la réponse à la stimulation. Il devient évident que des blocages plus discrets de la transmission neuromusculaire ne seront pas détectés par ce test.

La stimulation tétanique, pendant cinq secondes, constitue un test plus sensible mais il est douloureux et ne saurait s'appliquer à un malade non anesthésié. La stimulation en salves (trainof-four) a l'avantage de ne pas ètre douloureuse et de ne pas nécessiter de contrôle. Encore là cependant, on peut observer une réponse normale si moins de 70 pour cent des récepteurs sont occupés. Le test n'est donc pas plus sensible que la stimulation tétanique.

B. Myorésolutif et respiration: Malgré l'importance du sujet, on trouve peu de travaux établissant la corrélation entre un test de fonction neuromusculaire et la normalité de la ventilation. D'après Walts, une contraction musculaire soutenue sous stimulation tétanique permet d'affirmer que le malade a recouvré 90 pour cent de sa capacité vitale et de sa ventilation volontaire maximale.

La comparaison des tests entre eux est particulièrement difficile: il faut savoir entre autre que la sensibilité dépend de l'intensité de la stimulation et de sa durée. Pour le moment, l'au- 
teur recommande l'utilisation de plusieurs tests où tant la durée que l'intensité de la stimulation sont variées.

Quantification des récepteurs actifs: cette technique mise au point par Waud et Waud, estime la fraction des récepteurs bloqués par un relaxant non dépolarisant par l'observation de la courbe dose-réponse à la succinylcholine, d'abord en l'absence et ensuite en présence du dépolarisant. Par exemple, en présence de dtubocurarine, 100 nanomoles de succinylcholine sont nécessaires pour obtenir le même degré de dépolarisation que 10 nanomoles arrivent à produire en l'absence de d-tubocurarine; puisqu'il faut décupler la dose pour obtenir une mème réponse, on en conclut que 10 pour cent des récepteurs sont libres d'agir ou, inversement, que 90 pour cent des récepteurs sont neutralisés par le myorésolutif.

\section{Conclusion clinique}

Finalement, on ne sait pas quel pourcentage de récepteurs doit ètre disponible pour garantir une force musculaire suffisante pour une toux efficace ou pour vaincre une obstruction respiratoire.

\section{Autres facteur's modifiant l'action du myorésolutif ou de son antagoniste}

Intensifé du bloc: L'intensité du bloc au moment de l'administration de l'antagoniste, déterminera la vitesse et l'étendue de l'action de celui-ci. Plus le bloc est profond, plus il faut de temps pour un retour aux valeurs contrôle.

Nature du relaxant: La gallamine résiste davantage à la néostigmine que la d-tubocurarine ou le pancuronium. Il faut plus de néostigmine pour renverser le bloc attribuable à la gallamine.

Equilibre acido-basique: Lacidose respiratoire peut augmenter un bloc non dépolarisant mais, surtout lorsqu'elle est importante $\left(\mathrm{Pa}_{\mathrm{CO}_{2}}>\right.$ $50 \mathrm{mmHg}$ ), elle rend impossible le renversement du bloc.

On pourrait théoriquement prédire la même situation en présence d'acidose métabolique mais la chose n'a pas été prouvée jusqu'ici.

Cependant, il est surprenant de constater que l'alcalose métabolique rend difficile le renversement du bloc à la d-tubocurarine et au pancuronium par la néostigmine. Ces résultats sembleraient indiquer que le $\mathrm{pH}$ extracellulaire n'a pas autant d'importance que le $\mathrm{pH}$ intracellulaire et les concentrations ioniques.

Electrolytes: Il semble que l'hypokaliémie potentialise l'effet des relaxants non dépolarisants et affaiblit l'action de la néostigmine.
Cependant, la situation n'est pas simple et il faut tenir compte de différents facteurs: site d'action pré ou post-synaptique, maladie aiguë ou chronique, déshydratation, etc. Cependant, il est difficile d'isoler l'effet spécifique de la kaliémie car chez ces malades, plusieurs facieurs jouent en même temps. Chez des chats traités avec diurétiques sans supplément de potassium, l'auteur pense avoir réalisé une situation s'approchant de l'hypokaliémie chronique comme en rencontrent les anesthésistes. A partir des travaux effectués avec ce modèle expérimental, l'auteur affirme que les changements de la kaliémie semblent avoir peu de conséquences.

Facteurs pharmacocinétiques qui peuvent modifier l'activité du relaxant ou de son anragoniste: L'auteur passe en revue les éléments tels que le métabolisme des relaxants, l'insuffisance rénale, l'insuffisance hépatique, Thypothermie.

Les antagonistes: A ce chapitre, un nouveau médicament a récemment fait son apparition: la 4-aminopyridine qui aurait, d'après des études chez l'animal, plusieurs avantages sur la néo. stigmine ou la pyridostigmine:

plus longue durée d'action, antagonisme du blocage neuromusculaire attribuable aux antibiotiques (où la néostigmine n'agit pas), aucune action muscarinique dispensant de l'emploi de l'atropine.

Cependant, l'auteur ne voit pas un brillant avenir à cet antagoniste car les doses nécessaires pour antagoniser un bloc neuromusculaire stimulent aussi le système nerveux central et provoquent de l'agita\$-tion et de la confusion postopératoire. Idéalement, il faudrait une 4aminopyridine qui ne traverse pas la barrière hémato-encéphalique.

Il y aurait probablement avantage à l'associer à la néostigmine ou la pyridostigmine: cette association permettrait de réduire la dose de chaque médicament, ainsi que la dose d'atropine. Des études supplémentaires seront nécessaires.

L'auteur termine en cherchant à répondre à une question qui lui est souvent posée: que fait-on lorsqu'une dose de néostigmine ou de pyridostigmine habituellement suffisante n'arrive pas à antagoniser un bloc neuromusculaire?

Selon l'auteur, il n'y a pas lieu de donner de dose supplémentaire avanı d'avoir répondu aux questions suivantes:

1. A-t-on laissé suffisamment de temps à la médication pour agir?

2. Le bloc neuromusculaire est-il trop intense pour être vëritablement antagonisé? 
3. Quel est l'état acido-basique et ionique du malade?

4. Quelle est sa température?

5. Le malade reçoil-il quelques médicaments interférents?

6. L'excrétion du relaxant est-elle diminuée?

A l'exception de la question no 5 , cette revue permet de répondre à ces questions. On trouvera réponse à la question no 5 en consultant les articles visés par les références 12 et 34 de ce travail.

\section{REFERENCES}

1. HoRowItz, P.E. \& SPECTOR, S. Determination of serum d-tubocurarine concentration by radioimmunoassay. J. Pharmacol. Exp. Therap. 185: 94 (1973).

2. Cronnelly, R., Stanski, D.R., Miller, R.D., SHEINER, L.B., \& SOHN, Y.J. Renal function and the pharmacokinetics of neostigmine in anesthetized man. Anesthesiology (submitted for publication).

3. Kersten, V.W., Meijer, D.K.F., \& Agoston, S. Fluorimetric and chromatographic determination of pancuronium bromide and its metabolites in biological materials. Clin. Chem. Acta 44: 59 (1973).

4. KATZ, R.L. Neuromuscular effects of d-1ubocurarine, edrophonium and neostigmine in man. Anesthesiology 28: 327 (1967).

5. KarIS, J.H. \& Gissen, A.J. Evaluation of new neuromuscular blocking agents. Anesthesiology 35: 149 (1971).

6. Savarese, J.J., Antonio, R.P., \& Ginsburg, S. Potential uses of short-acting nondepolarizing neuromuscular blocking agents as predicted from animal experiments. Anesth. Analg. 54: 669 (1975).

7. WAUD, B.E. \& WAUD, D.R. The relation between tetanic fade and receptor occlusion in the presence of competitive neuromuscular block. Anesthesiology 35: 456-464 (1971).

8. Ali, H.H. UtTing, J.E. \& Gray, C.T. Quantitaive assessment of residual antidepolarizing block (pt 1). Brit. J. Anaesth. 43: 473-477 (1971).

9. WAUD, B.E. \& WAUD, D.R. The relation between the response to "train-of-four" stimulation and receptor occlusion during competitive neuromuscular block. Anesthesiology 37: 413-416 (1972).

10. WALTS, L.F., LEVIN, N., \& Dillon, J.B. Assessment of recovery from curare. J.A.M.A. 213: 1894-1896 (1970).

11. JOHANSEN, S.H. JORGENSEN, M. \& MOLAECK, S. Effect of tubocurarine on respiratory and nonrespiratory muscle power in man. J. Appl. Physiol. 19: 990-994 (1964).

12. MILLER, R.D. Antagonism of neuromuscular blockade. Anesthesiology 44: 293-304 (1976).

13. WAUD, B.E. \& WAUD, D.R. Physiology and pharmacology of neuromuscular blocking agents, in Katz, R.L. (ed.): Muscle Relaxants. Amsterdam. Excerpla Medica, North Holland Publishing Co., pp. I-58 (1975).
14. KaTz, R.L. Clinical neuromuseular pharnacology of pancuronium. Anesthesiology 34: 550-556 (1971).

15. Monks. $S$. The reversal of nondepolarizing relaxants. Anaesthesia 27: 313-318 (1972).

16. Miller, R.D., Larson, C.P., JR., \& WaY, W.L. Comparative antagonism of $\mathrm{d}$-tubocururinegallamine-. and pancuronium-induced neuromuscular blockades by neostigmine. Anesthesiology 36: 503-509 (1972)

17. Miller, R.D., Van Nymuis, L.S., Eger, E.1., II, et al. The effect of acid-base balance on neo. stigmine antagonism of d-tubocurarine-induced neuromuscular blockade. Anesthesiology 42: $377-383$ ( 1975 ).

18. Miller, R.D. \& Roderick. L. The influence of acid-base changes on neostigmine antagonism of a pancuronium neuromuscular blockade. Brit. J. Anaesth. 50: 317 (1978).

19. Feldoman, S.A. Effect of changes in electrolytes, hydration. and $\mathrm{pH}$ upon the reactions to muscle relaxants. Brit. J. Anaesth. 35: 546-551 (1963).

20. Comen, E.N. Patients with altered sensitivity. Clin. Anesth. 2: 76-93 (1966).

21. Cunningham, J.N.,Jr, Carter, N.W., Rector, F.C., JR., et al. Resting transmembrane potential difference of skeletal muscle in normal subjects and severely ill patients. J. Clin. Invest, 50: 49-59 (1971).

22. MILLER, R.D. \& Roderick. L. Diuretic-induced hyperkalemia and a pancuronium neuromuscular blockade and its antagonism by neostigmine. Brit. J. Anaesth. 50: 541 (1978).

23. Miller, R.D., Matreo, R., Benet, L.Z \& SoHN, Y.J. Influence of renal failure on the pharmacokinetics of d-tubocurarine in man. $J$. Pharmacol. Exp. Ther. 202: 1-7 (1977).

24. Miller, R.D. \& Eger, E. I. II. Early and late relative potencies of pancuronium and d-tubocurarine in man. Anesthesiology $44: 297$ (1976).

25. Miller, R.D., Agoston, S., BoolJ, L.D.H.J., Kersten, U., Crul, J.F., \& HaM, J. Comparative potency and pharmacokinetics of pancuronium and its metabolites in anesthetized man. J. Pharmacol. Exp. Ther. 207: 539 (1978)

26. MCLEOD, K. et at. Pharmacokinetics of pancuronium in patients with normal and impaired renal function. Brit. J. Anaesth. 48:341 (1976).

27. Buzello, W. \& Acoston, S. Kinetics of intercompartmental disposition and excretion of tubocurarine, gallamine. alcuronium and pancuronium in patients with normal and impaired renal function. Anesthesist 27: 319 (1978),

28. Somogvi, A.A., Shanks. C.A., \& Triggs, E.J. Disposition kinetics of pancuronium bromide in patients with total biliary obstruction. Brit. J. Anaesth. 49:1103 (1977).

29. Ham, J, Miller, R.D., Benet, L.Z. \& Matteo, R. The effect of temperature on the pharmacokinetics and pharmacodynamics of d-tubocurarine. Anesthesiology (In press).

30. Miller, R.D., Agoston, S., van der Pol, F. BoolJ, L.D.H.J., CruL, J., \& HAM, J. Hypothermia and the pharmacokinetics and pharmacodynamics of pancuroniurn in the cat. J. Pharmacol. Exp. Ther. (In press). 
31. Harvey, A.L. \& Marshall, I.G. The actions of three diaminopyridines on the chick biventer cervicis muscle. Europ. J. Pharmacol. 44: 303 (1977).

32. Miller, R.D., Dennissen, P.A.F., Van Der Pol,

F. \& AGoston, S. Potentiation of neostigmine and pyridostigmine by 4-amino-pyridine in the rat. $\mathrm{J}$. Phatm. Pharmacol. 30:699 (1978).
33. Miller, R.D., BoolJ, L.H.D.J., Agosron, S., \& CRUL, J,F, 4-Aminopyridine potentittes neostigmine and pyridostigmine in man. Anesthesiology (In press).

34. ALI, H.H. \& SAVARESE, J.J. Monitoring of neuromuscular function. Anesthesiology 45: 216 (1976). 